\title{
The invasive amphipod Gammarus tigrinus Sexton, 1939 conquering the north of Europe using a new pathway: the first recordings from Norway
}

\author{
Ingvar Spikkeland', Jorn Bohmer Olsen', Ragnar Kasbo, Kjell Magne Olsen ${ }^{4}$ and Jens Petter Nilssen 5
}

\begin{abstract}
Spikkeland I, Bøhmer Olsen J, Kasbo RJ, Olsen KM and Nilssen JP. 2020. The invasive amphipod Gammarus tigrinus Sexton, 1939 conquering the north of Europe using a new pathway: the first recordings from Norway. Fauna norvegica 40: 130-136.
\end{abstract}

\begin{abstract}
The invasive amphipod Gammarus tigrinus has during the last decades spread to large parts of Northern Europe, mainly using pathways eastwards from The British Isles to Continental Europe and further northeast into the Baltic Sea. From the coastline it has to some extent spread further inland, especially in topographically low-relief landscapes with highly polluted rivers. This account reports another geographical direction of dispersal, towards north into Southern Norway. In coastal brackish-water regions G. tigrinus may displace other gammarids. Large parts of Norway consist of high-relief landscapes close to many estuaries, so the further spread into this country is doubtful. However, if the taxon can avoid the initial barriers using vectors and spread into new watercourses above such barriers and thrive in this new ambient water chemistry, it may have large negative influence on the other benthic fauna. But Norwegian lakes and rivers are most probably too electrolyte-poor to support this species. However, in estuaries and other brackish waters along the coast, at least in the southern part of Norway, the species will thrive. Gammarus tigrinus is the only known intermediate host for the native American acanthocephalan parasite Paratenuisentis ambiguus, which has the American eel as its main host. This parasite also infects the European eel, and this poses an additional threat to the already endangered eel in Norwegian rivers where G. tigrinus has been recorded.
\end{abstract}

doi: 10.5324/fn.v40i0.3582. Received: 2020-05-08. Accepted: 2020-06-25. Published online: 2020-09-09. ISSN: $1891-5396$ (electronic).

Keywords: Gammarus tigrinus, amphipoda, non-indigenous species (NIS), estuary, Norway

1. Østfold Museum Foundation, Dep. Haldenvassdragets Kanalmuseum, P.O. Box 64, NO-1871 Ørje, Norway

2. Refneveien 13, NO-1771 Halden, Norway

3. Müller-Sars Biological Station, Ørje, P.O. Box 64, NO-1871 Ørje, Norway

4. BioFokus, Gaustadalléen 21, NO-0349 Oslo

5. Müller-Sars Society for Free Basic Research, Division of Biogeography and Ecology, P.O. Box 170, NO-4952 Risør, Norway.

Corresponding author: Ingvar Spikkeland

E-mail:ingvar.spikkeland@ostfoldmuseene.no

\section{INTRODUCTION}

Gammarus tigrinus Sexton, 1939 is a North American crustacean (order Amphipoda) which has invaded vast areas of Europe during the last 100 years, both in brackish and fresh waters (Figure 1). G. tigrinus is native to brackish waters along the Atlantic coast of North America, from southern Labrador to Florida. The species has been introduced to different areas of the USA (including the Great Lakes), Europe and Venezuela in South America (Shaleva 2014). The first records in Europe were in England and Ireland in 1931. In 1957 the species was intentionally introduced to two polluted rivers in Germany where the native amphipods had disappeared, and from there it spread to other German inland waters. Later on it was found in the Netherlands (1964), Belgium (1995) and France (2005). The earliest record from the Baltic Sea is from the German coast in 1975, and from there it has spread rapidly towards east and north, and it is now recorded from all the countries bordering the Baltic Sea (Figure 1, see Rewicz et al. 2019 for a review of the immigration history). The species has so far not been part of Norwegian fauna according to an overview of Norwegian gammarids provided by Vader \& Tandberg (2019). However, during an investigation on the benthic fauna of River Tista in Halden town, southeastern Norway, Gammarus tigrinus was recorded in large number along the river shore in September 2018, which makes it the first Norwegian confirmation. In July 2019, the species was also recorded in River Drammenselva in the Oslo Fjord Area (Figure 1).

Among the recent non-indigenous species in the Baltic Sea, Gammarus tigrinus is regarded as one of the more aggressive invaders (Kotta et al. 2013). The species has a high tolerance to salinity changes (0-25 psu), but also to pollution and human degradation of the environment. Furthermore, G. tigrinus has high fertility, early maturity, and high number of generations pr. year (Grabowski et al. 


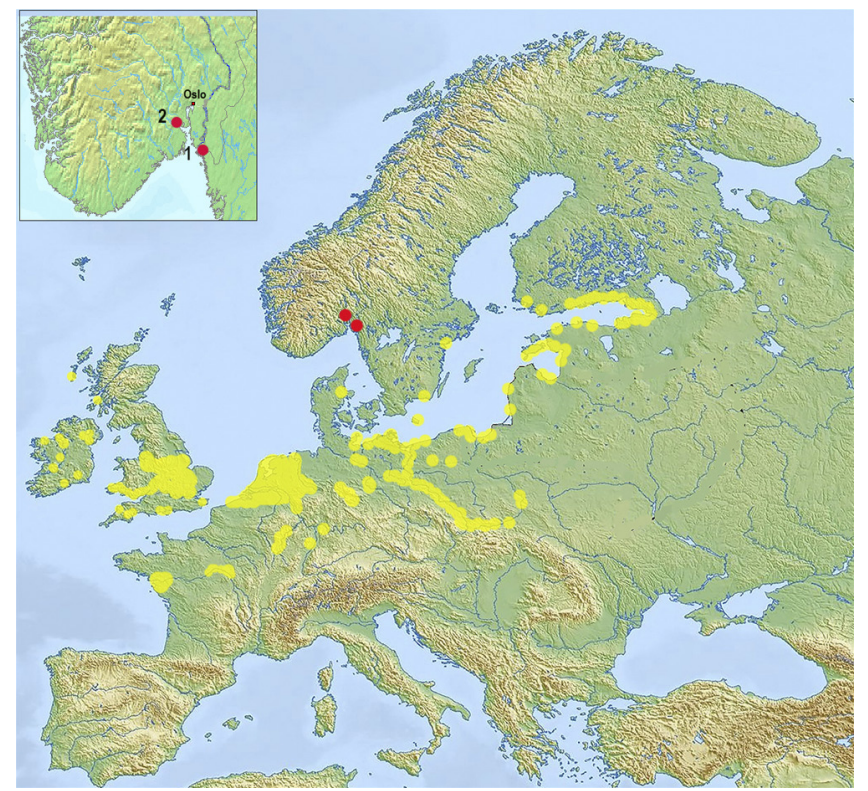

Figure I. The occurrence of Gammarus tigrinus in Europe (yellow dots and yellow areas, redrawn from Rewicz et al. 2019). The Norwegian recordings shown in red dots. 1: River Tista, 2: River Drammenselva. (Underlying map: Wikipedia Commons).

2007a). Due to these traits, this species is a very potent competitor, and has replaced indigenous gammarid species in most of the invaded habitats (Pinkster et al. 1992, Grabowski et al. 2006, Herkül \& Kotta 2007, Reisalu et al. 2016).

\section{MATERIAL AND METHODS}

\section{River Tista, Southeast Norway}

River Tista constitutes the lower part of the Halden watercourse and extends $4 \mathrm{~km}$ from Tistedal town to the Idde Fjord. The Halden watercourse is a $130 \mathrm{~km}$ long watercourse in SE Norway, located along the border to Sweden, with a catchment area of $1584 \mathrm{~km}^{2}$ (Figure 2). About $80 \mathrm{~km}$ of the river is canalized, with locks at Brekke, Strømsfoss and Ørje, but River Tista is not a part of the canal, due to the high waterfall at Tistedalsfoss (66 m). Downstream of the Tistedalsfoss waterfall, there are locks at Skonningsfoss and Porsnes, but these locks are now closed down (Figure 3). There are salmon ladders both at Porsnes and Skonningsfoss, permitting salmon and sea trout to migrate up to the waterfall at Tistedal.

The benthic fauna of River Tista was studied in September 2018 at 5 different sampling sites, from the Tistedalsfoss waterfall and down to the outlet at Idde Fjord (Figure 3). Along the river shore, the bottom substrate, mainly stones, gravel and detritus, was kicked up and animals silted off by a hand net (sieve size $1 \mathrm{~mm}$ ). The net was also used for scratching macrophytes and soft bottom, mainly at sampling Site 4. Stones and other bottom material were also examined, and animals picked off by hand. In addition to sampling along the shore, benthic samples were taken at the deepest part of the river (3-4 m depth) at the sampling Sites 1-3, using a boat and a bottom trawl designed for sampling bottom dwelling glacial relict crustaceans. The sampling was a bit difficult, due to quite rough bottom conditions.

There also exist five samples of the benthic fauna from September 1998, sampled by students at Østfold College, Halden, southeast Norway. The exact locations of these samples are not known, but all

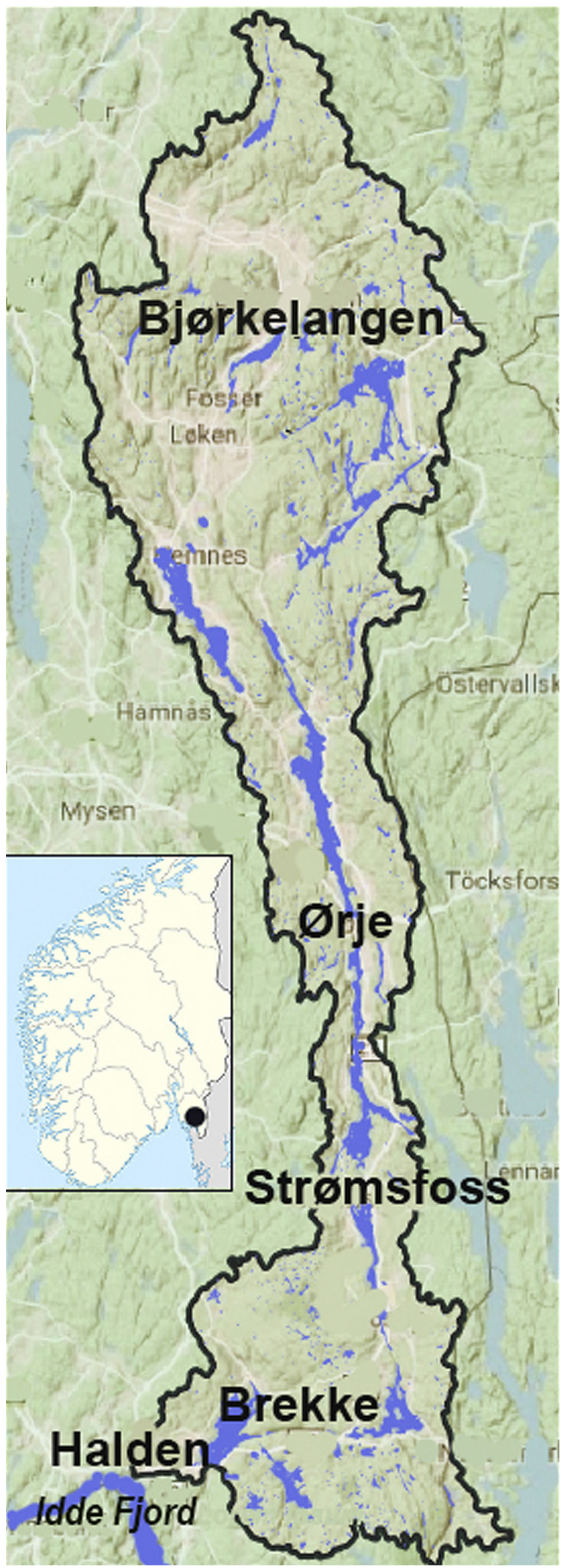

Figure 2. Halden watercourse, SE Norway. 


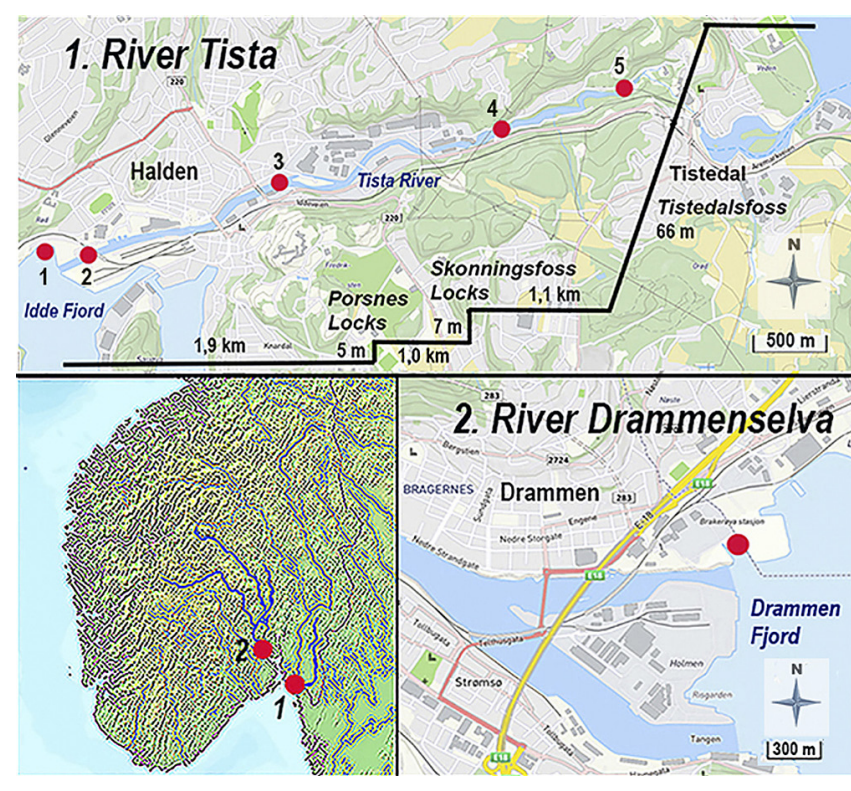

Figure 3. River Tista and River Drammenselva, SE Norway. The sampling sites are indicated with red dots. River Tista with locks/waterfalls and elevation differences are indicated. (Underlying map: (C) 2020 Norkart AS/ Geovekst og kommunene/NASA, Meti (C Mapbox @ OpenStreetMap).

are from the part of the river influenced by saline water or from the Idde Fjord. The sampling methods used in 1998 were only qualitative, while the methods used in 2018 were semi-quantitative, and thus give some information on the abundance of the different species. The Gammarus species were determined by using the keys in Zettler \& Zettler (2017) and Vader \& Tandberg (2019). The nomenclature is in accordance with Zettler \& Zettler (2017).

The river downstream Porsnes locks is influenced by saline water from the fjord (Table 1), and quite polluted from industrial and sewage drains, but has been cleaner during the recent decades due to purification measures. Above the locks the main river is characterized by low levels of electrolytes (specific conductivity $5.5-8.0 \mathrm{mS} / \mathrm{m}$ ), although it is moderately polluted by runoff from agriculture, especially in the northern part of the catchment area.

Table I. Sampling sites, conductivity and salinity of River Tista 18 September, 2018.

\begin{tabular}{|c|c|c|c|c|}
\hline $\begin{array}{l}\text { Site } \\
\text { no. }\end{array}$ & Station & $\begin{array}{c}\text { Geographical coord. } \\
\text { (latitude/longitude) }\end{array}$ & $\begin{array}{c}\text { Conductivity } \\
\left(\mathrm{mSm}^{-1}\right)\end{array}$ & $\begin{array}{l}\text { Salinity } \\
\text { (ppt) }\end{array}$ \\
\hline 1 & $\begin{array}{l}\text { River outlet/ } \\
\text { Idde Fjord }\end{array}$ & $59.119 / 11.368$ & 853 & 4.8 \\
\hline 2 & Railway Bridge & $59.119 / 11.370$ & 532 & 2.9 \\
\hline 3 & Porsnes & $59.123 / 11.396$ & 236.5 & 1.2 \\
\hline 4 & Fosseløkka & $59.126 / 11.421$ & 7.1 & 0 \\
\hline 5 & Tistedal & $59.130 / 11.437$ & 6.6 & 0 \\
\hline
\end{tabular}

Table 2. Recorded Gammaridae species in River Tista/Idde Fjord 1998 and 2018

\begin{tabular}{lcc}
\hline Species & 1998 & 2018 \\
\hline Echinogammarus marinus (Leach, 2015) & $\mathrm{x}$ & \\
Echinogammarus finmarchicus (Dahl, 1938) & $\mathrm{x}$ & \\
Gammarus duebeni Lilljeborg, 1852 & $\mathrm{x}$ & $\mathrm{xx}$ \\
Gammarus tigrinus Sexton, 1939 & & $\mathrm{xxx}$ \\
Gammarus zaddachi Sexton, 1912 & $\mathrm{xx}$ & $\mathrm{x}$ \\
\hline
\end{tabular}

\section{River Drammenselva, Southeastern Norway}

River Drammenselva forms the lower parts of the Drammen watercourse, from Lake Tyrifjorden to the Drammen Fjord (47 $\mathrm{km})$. The Drammen watercourse is the third largest watercourse in Norway (catchment area $17114 \mathrm{~km}^{2}$ ). During an impact assessment in connection with the construction of a new hospital and the development of "Fjordbyen Lierstranda" in inner Drammen Fjord, samples were taken of underwater vegetation in a small, artificial bay near the northern outlet of River Drammenselva (EU89: N 59.740, E 10.238, Figure 3) on 17 July, 2019, and among the plants, some benthic animals were also recorded and identified.

\section{RESULTS AND DISCUSSION}

\section{Species of Gammaridae in the River Tista}

The lower part of the River Tista used to support several Gammaridae species. In the samples from 1998, four species were recorded; the typical brackish water species Gammarus duebeni Lilljeborg, 1852 and Gammarus zaddachi Sexton, 1912, and the more salt-water tolerant Echinogammarus marinus (Leach, 1815) and Echinogammarus finmarchicus (Dahl, 1938). Based on the samples from 1998, we know little about the abundance of the different species, but the samples indicate that G. zaddachi was the most numerous species, while $E$. marinus and E. finmarchicus were confined to two of the samples, probably from the more saline Idde Fjord (Table 2).

In the littoral samples from 2018, only Gammarus species were recorded. Gammarus tigrinus was the dominant species at Sites 1, 2 and 3 (Table 3), and appeared in large numbers, especially at Site 1 and 3. Gammarus zaddachi and Gammarus duebeni were recorded in small numbers, and only from the river outlet (Site 1). At Site 4 no Gammarus specimens were recorded, while three juveniles were found at Site 5 (species unknown). Except for the three juveniles at Site 5, Gammarus specimens were only found in the part of the river influenced by saline water (Sites $1-3$ ). Due to the barriers at Porsnes and Skonningsfoss, G. tigrinus will not be able to migrate further upstream without being carried by a vector, i.e. water birds, anglers etc. (Rachalewski et al. 2013, Anderson et al. 2014). The juvenile gammarids at Site 5 probably belong to another Gammarus species.

In the bottom trawl samples, Gammarus tigrinus was the only Gammaridae species recorded, but appeared in low number. At Sites $1-3$, the number of specimens were 1,3 and 6 respectively, indicating that $G$. tigrinus prefers shallow areas along the shore. The material, especially from the shallow areas, also shows that G. tigrinus was most abundant at Site 3. Another invasive species, the New Zealand mud snail Potamopyrgus antipodarum (Gray, 1843), was abundant both in the trawl samples and along the shore. The Ponto-Caspian hydroid Cordylophora caspia (Pallas, 1771), also used to live in River Tista, but was not recorded in 2018.

Table 3. Number of different Gammarus species in River Tista September 2018. The samples are from the shallow areas along the shore.

\begin{tabular}{cccccc}
\hline Site & $\begin{array}{c}\text { Salinity } \\
(\mathrm{ppt})\end{array}$ & G. tigrinus & G. duebeni & G. zaddachi & Juv. \\
\hline 1 & 4.8 & 73 & 18 & 4 & 444 \\
2 & 2.9 & 10 & 0 & 0 & 65 \\
3 & 1.2 & 132 & 0 & 0 & 408 \\
4 & 0 & 0 & 0 & 0 & 0 \\
5 & 0 & 0 & 0 & 0 & 3 \\
\hline
\end{tabular}


The material indicates that $G$. tigrinus has replaced the other Gammaridae species in the saline-influenced part of River Tista with lowest salinity $(1.2-2.9 \mathrm{ppt})$, while the brackish water species Gammarus duebeni and Gammarus zaddachi still live at the outlet, where the salinity is higher. More research throughout the season is needed to see if this applies in general, but this is in accordance with observations elsewhere along the European coasts (Pinkster \& Platvoet 1983, Jażdżewski et al. 2005, Daunys \& Zettler 2006, Reisalu et al. 2016).

\section{River Drammenselva/Drammen Fjord}

Among the plants sampled at the river outlet (Figure 3), there were one male specimen of Gammarus tigrinus, a large number of the invasive New Zealand mud snail Potamopyrgus antipodarum and a few other invertebrates. The sampling was not designed to collect animals, so the list is incomplete, and the distribution of G. tigrinus in the area is not known. Potentially, there are large areas both inside and outside the small bay where it might thrive.

During an investigation in the inner part of Drammen Fjord in 2008 (Haugen et al. 2009), the following crustacean species were recorded: Gammarus zaddachi, Gammarus locusta and Corophium volutator, and in addition one unidentified Gammarus specimen. Invasion of Gammarus tigrinus in River Drammenselva and Drammen Fjord will probably have negative impact on the other Gammarus species, and especially on G. zaddachi (Jażdżewski et al. 2004, Grabowski et al. 2006).

\section{Gammarus tigrinus - morphological identification}

Gammarus tigrinus is a small-sized amphipod. Average body length of a full-grown male is $10,5-12,5 \mathrm{~mm}$, female $8,5-10,0 \mathrm{~mm}$. Body colour of the living animal is whitish to yellow/faint orange, with black and red patches or transverse stripes (Figure 4), which has given the species its specific name tigrinus. Mature males typically have 2-5 groups of posterior marginal setae in the second peduncular (basal) segment of their first antennae, longer and curly setae on the second antennae, and distinct, curly setae on their pereopods. Urosome segments are without long setae, but with a few short setae and spines. Uropod 3 is long and setose, and inner ramus is about $75-80$ percent of the length of outer ramus. Figure 5 shows some of these anatomical features. Females have fewer setae at the antennae and pereopods, and since they are generally smaller, the morphological differences between the sexes are much more noticeable in this species compared with other species in the genus (Zettler \& Zetter 2017).

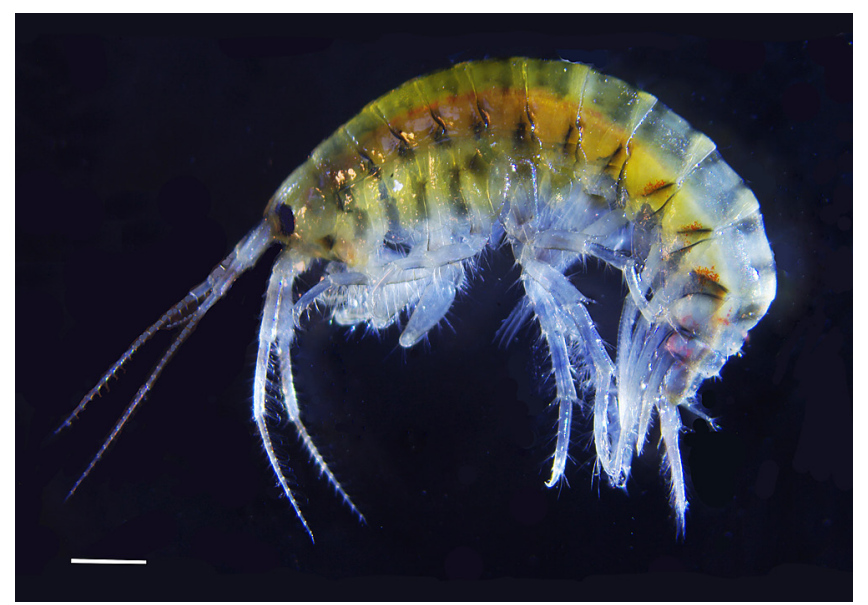

Figure 4. Male Gammarus tigrinus from River Tista. Scale bar: $1 \mathrm{~mm}$. (Photo: Ingvar Spikkeland).

\section{Dispersal of Gammarus tigrinus to Norway}

The main dispersal vector for Gammarus tigrinus around the Baltic Sea and elsewhere seems to be international shipping, in ballast water or in fouling on the ship's hull (Ba et al. 2010). The Norwegian populations are probably spread by ballast water from Baltic or West European ports to the ports of Halden and Drammen. To reach these ports, the ships have to cross areas with salinities close to $35 \mathrm{ppt}$, and G. tigrinus would probably not be able to survive such high salinities on the ship's hull.

We expect that Gammarus tigrinus in the future will colonize many estuaries along the Norwegian coast, especially ports with international shipping. Due to the generally high salinities along the Norwegian coast, G. tigrinus would not be able to spread from one estuary to another without being transported by a vector. But in certain areas with lower salinities, such as many Norwegian fjords, $G$. tigrinus will probably be able to immigrate to new areas on its own. In the Oslo Fjord area (including Drammen Fjord), we expect rapid dispersal of the species.

In most of its distribution area, Gammarus tigrinus seems to be confined to low salinity bays, lagoons and estuaries, and does not migrate further up the rivers (Bousfield 1973, Pinkster \& Platvoet 1983, Arbačiauskas et al. 2011). However, in several heavily polluted rivers and canals in Central Europe (Rhein, Weser, Elbe, Oder, MainDonau-canal), G. tigrinus has spread during recent decades (Tittizer et al. 2000, Grabowski et al. 2007b).

\section{Gammarus tigrinus in Norway - possible ecological impacts}

Gammarus tigrinus tolerates a salinity range of 0 to $25 \mathrm{ppt}$ (Bousfield 1973). In Europe, the lower critical salinity level for survival is $0.2 \mathrm{ppt}$ (Shaleva 2014). According to Grabowski et al. (2009), alien amphipods in Polish rivers were found only occasionally in purely freshwater conditions, but in most of cases all the Ponto-Caspian species as well as G. tigrinus were present predominantly in places where the conductivity was higher than $60 \mathrm{mSm}^{-1}$. This is about 10 times as high conductivity as in River Tista and River Drammenselva. It therefore seems unlikely that $G$. tigrinus will penetrate into Norwegian freshwaters, as very few Norwegian rivers have conductivity above 60 $\mathrm{mSm}^{-1}$. Another limiting factor for G. tigrinus in Norway is cold and long-lasting winters. In the Netherlands severe and prolonged winters 1978 - 1979 and 1979 - 1980 caused a temporary decline in the $G$. tigrinus population (Pinkster et al. 1992).

If Gammarus tigrinus nevertheless manages to adapt to the chemical conditions in the Halden watercourse, it may potentially have negative impact on other crustaceans in this river system. The large and deep lakes dominating the watercourse upstream Halden (Figure 2), harbour all the Norwegian glacial relict crustaceans except the southern opossum shrimp Mysis salemaai Audzijonyte \& Vainola, 2005 (Spikkeland et al. 2016). In Irish lakes there is mutual predation between Gammarus tigrinus and Mysis salemaai (Bailey et al. 2006), and this probably also will be the case with its sibling species Mysis relicta Lovén, 1862 in the Halden watercourse. However, little is known about the relationship between $G$. tigrinus and the other indigenous glacial relict crustaceans in Halden watercourse, i.e. the amphipods Monoporeia affinis (Lindström, 1855), Pallaseopsis quadrispinosa (G.O. Sars, 1867) and Gammaracanthus lacustris G.O. Sars, 1867. These crustaceans belong to the deep water community, and are with few exceptions only found in lakes deeper than $20 \mathrm{~m}$. This would probably reduce both predation and competition with G. tigrinus, as G. tigrinus is mostly confined to shallow areas (Grigorovich et al. 2005, Jażdżewski \& Grabowski 2011), although some records show that it is able to survive at a water depth of below $15 \mathrm{~m}$ (Zettler \& Zettler 2017). 

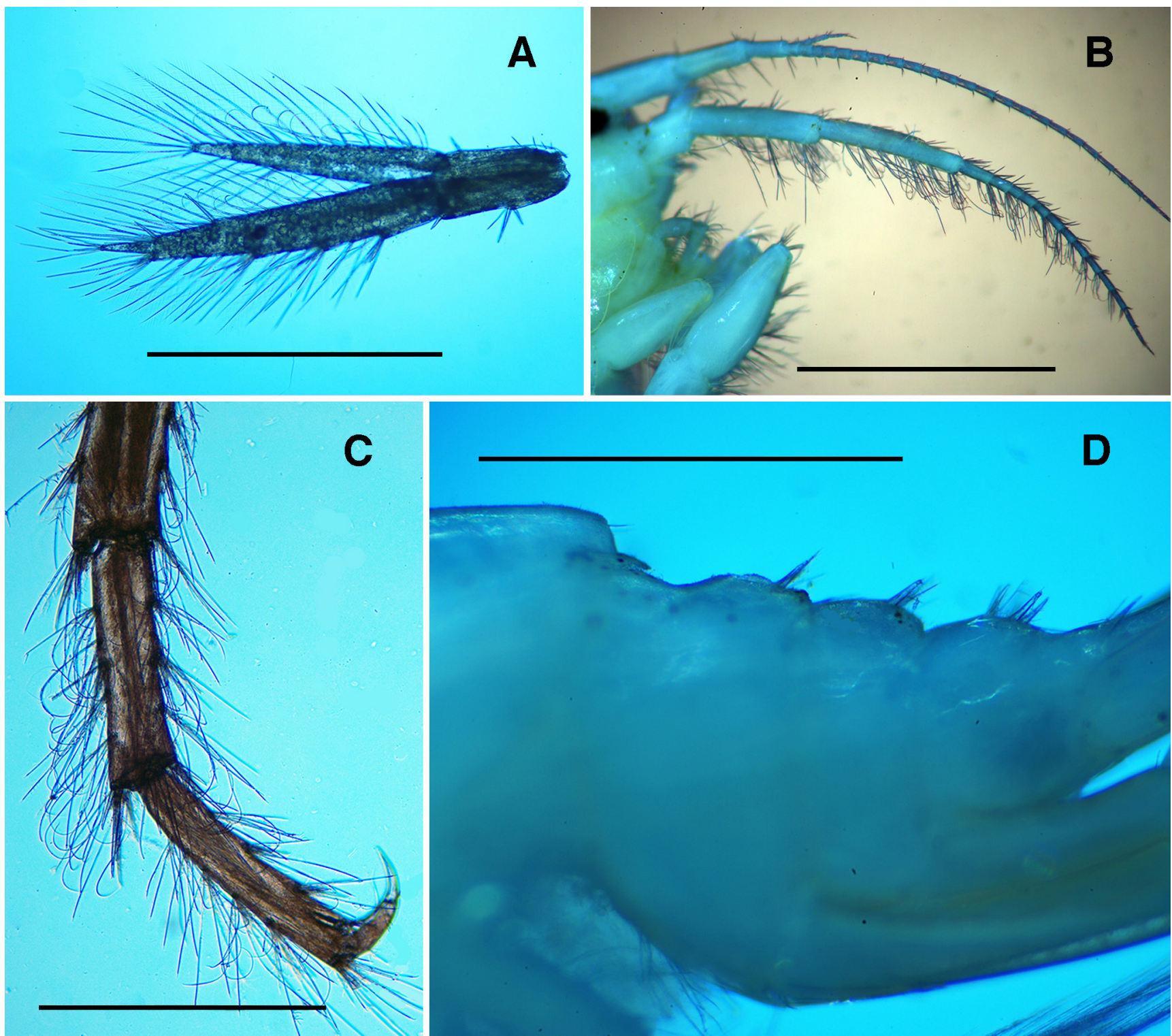

Figure 5. Morphological characteristics of male Gammarus tigrinus from River Tista. A: Uropod 3, B: Antennae 1 and 2, C: Pereopod 7 with curly setae, D: Urosome segments, with few short setae and spines. Scale bar: $1 \mathrm{~mm}$ (Photos: Ingvar Spikkeland).

The water chemistry in River Drammenselva is not very different from River Tista (Hagen 2017), although the catchment area of the Drammen watercourse contains areas with calcareous rocks, and locally has lakes and rivers with a higher content of ions and nutrients. Apart from the estuary and the saline part of the river, the only indigenous amphipod species in this watercourse is Gammarus lacustris G.O. Sars, 1864, but this species is often recorded in electrolyte-poor lakes.

If Gammarus tigrinus manages to adapt to Norwegian rivers and lakes, it is most likely to occupy watercourses in low relief landscapes most affected by water pollution, viz. southeast Norway, the Jæren region in the southwest and around the Trondheim Fjord in MidNorway.

Gammarus tigrinus is the only known intermediate host for the acanthocephalan parasite Paratenuisentis ambiguus Van Cleave, 1921, which has the American eel Anguilla rostrata (Lesueur, 1817) as its main host. The parasite has probably been spread to Europe together with G. tigrinus, and has been detected in European eel Anguilla anguilla (Linnaeus, 1758) both in Germany and Poland, where it is shown to employ the same crustacean intermediate host as in North America, i.e. G. tigrinus (Samuel \& Bullock 1981, Taraschewski et al. 1987, Morozińska-Gogol 2008). The European eel is a vulnerable species in Norway and critical endangered globally (Jacoby \& Gollock 2014, Henriksen \& Hilmo 2015, ICUN 2020), and it is likely that the parasite will infect eels in Norwegian rivers and thus pose an additional threat to the eel population here.

\section{CONCLUSION}

The present recordings of the invasive North American amphipod Gammarus tigrinus in Southern Norway diverges from the earlier dissemination of this species in North Europe. Earlier this taxon has followed the pathways from The British Isles and eastwards to Continental Europe, and then north-eastwards into the Baltic region. In the Baltic Sea, it has spread contraclockwise all the way around. From the coastline it has spread further inland as well, especially in highly polluted rivers and canals. Now G. tigrinus is about to colonize the Norwegian Coast. We expect the species to spread further in estuaries and brackish waters along the coast, at least in the southern part of the country with a relative mild climate. Most lakes and rivers in Norway are probably too electrolyte-poor for this invasive species, 
but it is possible that the most polluted rivers will provide a suitable habitat. G. tigrinus is the intermediate host for the acanthocephalan parasite Paratenuisentis ambiguus, which has the American eel as its main host, and the parasite has recently been shown to infect the European eel as well. G. tigrinus probably has spread the parasite to Norwegian rivers, and this poses an additional threat to the already endangered Norwegian eel population.

\section{ACKNOWLEDGEMENT}

We are grateful to Gøran Brattstrøm for linguistic correction, to Gunnar Hasle for notifying us about the capacity of Gammarus tigrinus to carry invasive parasites, and to Norwegian Mapping Authority for permission to use maps of Halden and Drammen. We furthermore thank Wim Vader and an anonymous referee for valuable comments on the manuscript.

\section{REFERENCES}

Anderson LG, White PCL, Stebbing PD, Stentiford GD, Dunn AM (2014). Biosecurity and Vector Behaviour: Evaluating the Potential Threat Posed by Anglers and Canoeists as Pathways for the Spread of Invasive Non-Native Species and Pathogens. PLoS ONE 9(4): e92788. doi: 10.1371/journal.pone.0092788.

Arbačiauskas K, Višinskienė G, Smilgevičienè S, Rakauskas V. 2011. Non-indigenous macroinvertebrate species in Lithuanian fresh water: Distribution, dispersal and future. Knowledge and Management of Aquatic Ecosystems 412 (12): 1-18. doi: 10.1051/kmae/2011075

Ba J, Hou Z, Platvoet D, Zhu L, Li S. 2010. Is Gammarus tigrinus (Crustacea, Amphipoda) becoming cosmopolitan through shipping? Predicting its potential invasive range using ecological niche modeling. Hydrobiologia 649: 183-194. doi: 10.1007/s10750-010-0244-5

Bailey RJE., Dick JTA, Elwood R, MacNeil C. 2006. Predatory interactions between the invasive amphipod Gammarus tigrinus and the native opossum shrimp Mysis relicta. Journal of the North American Benthological Society 25(2): 393-405. doi: 10.1899/0887-3593(2006)25[393:PIBTIA]2.0.CO;2

Bousfield EL. 1973. Shallow-water Gammaridean Amphipoda of New England. London, UK. Cornell University Press. 324 pp.

Daunys D, Zettler ML. 2006. Invasion of the North American amphipod (Gammarus tigrinus Sexton, 1939) into the Curion Lagoon, Southeastern Baltic Sea. Acta Zoologica Lituanica 16 (1): 20-26. doi: 10.1080/13921657.2006.10512705

Grabowski M, Konopacka A, Jażdżewski K, Janowska E. 2006. Invasion of alien gammarid species and retreat of natives in the Vistula Lagoon (Baltic Sea, Poland). Helgolander Marine Research 60: 90-97. doi: 10.1007/s10152-006-0025-8

Grabowski M, Bacela K, Konopacka A. 2007a. How to be an invasive gammarid (Amphipoda: Gammaroidea) - Comparison of life history traits. Hydrobiologia 590: 75-84. doi: 10.1007/s10750-007-0759-6

Grabowski, M., Jażdżewski, K, Konopacka A. 2007b. Alien Crustacea in Polish waters - Amphipoda. Aquatic Invasions 2(1): 25-38. doi: 10.3391/ai.2007.2.1.3

Grabowski M, Bacela K, Konopacka A, Jazdzewski K. 2009. Salinityrelated distribution of alien amphipods in rivers provides refugia for native species. Biol. Invasions 11:2107-2117. doi: 10.1007/s10530-0099502-8

Grigorovich IA, Kang M, Ciborowski JJH. 2005. Colonization of the Laurentian Great Lakes by the Amphipod Gammarus tigrinus, a Native of the North American Atlantic Coast. Journal of Great Lakes Research 31(3):333-342. doi: 10.1016/S0380-1330(05)70264-1

Hagen AG. 2017. Kartlegging av vannkjemi i Drammensvassdraget
[Survey of water chemistry in the Drammensvassdraget]. NIVA Rapport L.nr. 7142-2017. 36 pp. (In Norwegian).

Henriksen S, Hilmo O. (ed.) 2015. Norwegian red list for species 2015. Norwegian Biodiversity Information Centre. https://www.biodiversity. no/Pages/135380/Norwegian_Red_List_for_Species. Accessed 202005-04.

Herkül K, Kotta J. 2007. New records of the amphipods Chelicorophium curvispinum, Gammarus tigrinus, G. duebeni, and G. lacustris in the Estonian coastal sea. Proceedings of the Estonian Academy of Sciences. Biology, Ecology 56 (4): 290-296.

Haugen TO, Lund E, Bækken T, Mjelde M, Norling K. 2009. Biologisk undersøkelse av indre Drammensfjord med spesielt fokus på gruntvannsområdene [Biological study of the inner Drammensfjord with special focus on shallow water areas]. NIVA Rapport 5798-2009. 79 pp. (In Norwegian).

IUCN 2020. The IUCN Red List of Threatened Species. Version 2020-1. https://www.iucnredlist.org. Accessed 2020-05-04.

Jacoby D, Gollock M. 2014. Anguilla anguilla. The IUCN Red List of Threatened Species 2014: e.T60344A45833138. doi: 10.2305/IUCN. UK.2014-1.RLTS.T60344A45833138.en

Jażdżewski K, Konopacka A, Grabowski M. 2004. Recent drastic changes in the gammarid fauna (Crustacea, Amphipoda) of the Vistula River Deltaic system in Poland caused by alien invaders. Diversity and Distibutions 10: 81-86. doi: 10.1111/j.1366-9516.2004.00062.x

Jażdżewski K, Konopacka A, Grabowski M. 2005. Native and alien malacostracan Crustacea along the Polish Baltic Sea coast in the 20th century. Oceanological and Hydrobiological Studies 34 (Suppl. 1): 175-193.

Jażdżewski K \& Grabowski M. 2011. Alien Crustaceans Along the Southern and Western Baltic Sea. Pp. 323-244 in: Galil BS., Clarck, PF, Charlton JT. In the Wrong Place - Alien Marine Crustaceans: Distribution, Biology and Impacts. Invading Nature - Springer Series in Invasion Ecology, vol 6. Springer, Dordrecht. doi: 10.1007/978-94007-0591-3_11

Kotta J, Pärnoja M, Katajisto T, Lehtiniemi M, Malavin SA, Reisalu G, Panov VE. 2013. Is a rapid expansion of the invasive amphipod Gammarus tigrinus Sexton, 1939 associated with its niche selection: a case study in the Gulf of Finland, the Baltic Sea. Aquatic Invasions 8 (3): 319-332. doi: 10.3391/ai.2013.8.3.08

Morozińska-Gogol J. 2008. The first record of Paratenuisentis ambiguus (Acanthocephala, Tenuisentidae) in Poland. Oceanologia 50 (2): 275279.

Pinkster S, Platvoet D. 1983. Further observations on the distribution and biology of two alien amphipods, Gammarus tigrinus Sexton, 1939, and Crangonyx pseudogracilis Bousfield, 1958, in the Netherlands (Crustacea, Amphipoda). Bulletin Zoologisch Museum, Universiteit van Amsterdam 9: 154-164.

Pinkster S, Scheepmaker M, Platvoet D, Broodbakker N. 1992. Drastic changes in the amphipod fauna (Crustacea) of Dutch inland waters during the last 25 years. Bijdragen tot de Dierkunde 61(4): 193-204. doi: 10.1163/26660644-06104001

Rachalewski, M., Banha, F., Grabowski, M. \& Anastacio, P.M. (2013) Ectozoochory as a possible vector enhancing the spread of an alien amphipod Crangonyx pseudogracilis. Hydrobiologia, 717, 109- 117. doi: 10.1007/s10750-013-1577-7

Reisalu G, Kotta J, Herkül K, Kotta K. 2016. The invasive amphipod Gammarus tigrinus Sexton, 1939 displaces native gammarid amphipods from sheltered macrophyte habitats of the Gulf of Riga. Aquatic Invasions 11(1): 45-54. doi: 10.3391/ai.2016.11.1.05

Rewicz T, Grabowski M, Tończyk G, Konopacka A, Bącela-Spychalska K. 2019. Gammarus tigrinus Sexton, 1939 continues its invasion in the Baltic Sea: first record from Bornholm (Denmark). BioInvasions Records 8(4): 862-870. doi: 10.3391/bir.2019.8.4.14

Samuel G., Bullock W. L., 1981, Life cycle of Paratenuisentis ambiguus (Van Cleave, 1921) Bullock and Samuel, 1975 (Acanthocephala: Tenuisentidae). The Journal of Parasitology 67 (2): 214-217. doi: 


\section{$10.2307 / 3280638$}

Shaleva E. 2014. Gammarus tigrinus. Datasheet. CABI Invasive Species Compendium. http://www.cabi.org/isc/datasheet/82074. Date of access: 2020-03-31.

Spikkeland I, Kinsten B, Kjellberg G, Nilssen JP, Väinölä R. 2016. The aquatic glacial relict fauna of Norway - an update of distribution and conservation status. Fauna norvegica 36: 51-65. doi: 10.5324/ fn.v36i0.1994

Taraschewski H, Moravec F, Lamah T, Anders K. 1987. Distribution and morphology of two helminths recently introduced into European eel populations: Anguillicola crassus (Nematoda, Dracunculoidea) and Paratenuisentis ambiguus (Acanthocephala, Tenuisentidae). Diseases of Aquatic Organisms 3: 167-176.

Tittizer T, Schöll F, Banning M, Haybach A, Schleuter M. 2000. Aquatische Neozoen im Makrozoobenthos der Binnenwasserstrasse Deutschlands. Lauterbornia 39: 1-72.

Vader W, Tandberg AHS. 2019. Gammarid amphipods (Crustacea) in Norway, with a key to the species. Fauna norvegica 39: 12-25. doi: 10.5324/fn.v39i0.2873

Zettler ML, Zetter A. 2017. Marine and freshwater Amphipoda from the Baltic Sea and adjacent territories. ConchBooks. Harxheim. 845 pp.

Editorial responsibility: Anne Helene Tandberg.

This article is open-access and distributed under the terms of the Creative Commons Attribution 4.0 International license. This permits all noncommercial use, distribution, and reproduction in any medium, provided the original work is properly cited.

(http://creativecommons.org/licenses/by/4.0/). 